\title{
Effects of exogenous nitric oxide on growth of cotton seedlings under $\mathrm{NaCl}$ stress
}

\author{
Y.J. Dong ${ }^{1 *, 2}$, S.S. Jinc ${ }^{3}$, S. Liu ${ }^{1}$, L.L. Xu ${ }^{1}$, J. Kong ${ }^{1}$ \\ ${ }^{1}$ College of Resources and Environment, Shandong Agricultural University, Tai'an 271018, P.R.China. ${ }^{2}$ Shandong Provincial \\ Key Laboratory of Eco-Environmental Science for Yellow River Delta (Binzhou University), Binzhou 256600, P.R.China. ${ }^{3}$ \\ Sate Key Laboratory of Crop Biology, College of Life Sciences,Shandong Agricultural University, Tai'an 271018 P.R.China. \\ ${ }^{*}$ Corresponding author: yuanjiedong@163.com
}

\begin{abstract}
In the present investigation, the role of sodium nitroprusside (SNP, a donor of NO) in inducing salinity tolerance $(100 \mathrm{mM} \mathrm{NaCl})$ in cotton was studied. Salt stress reduced the values of photosynthetic attributes and total chlorophyll content and inhibited the activities of nitrate reductase. Furthermore, salt stress also induced oxidative stress as indicated by the elevated levels of lipid peroxidation compared to CK. The application of SNP at $1.00 \mathrm{mM}$ promoted the growth and restrained superoxide anions $\left(\mathrm{O}_{2} \cdot{ }^{-}\right)$generation rate. And activities of antioxidant enzymes, namely, catalase (CAT) and superoxide dismutase (SOD), were enhanced by SNP treatment. On the other hand, an increase in the $\mathrm{K}^{+}$content, antioxidant enzyme activities, along with a decrease in the $\mathrm{Na}^{+} / \mathrm{K}^{+}$ratio, the contents of thiobarbituric acid reactive substances (TBARS) and malondialdehyde (MDA) were observed in the NaCl-stressed seedlings subjected to the low level $(0.1 \mathrm{mM})$ SNP. These results indicated that the application of moderate SNP can be used to protect plants growth and induce its antioxidant defense system under salt stress.
\end{abstract}

Keywords: Antioxidant enzymes, cotton seedlings, mineral elements, reactive oxygen species, SNP; salt-tolerance

Abbreviations: $\mathrm{CAT}$, catalase; $\mathrm{H}_{2} \mathrm{O}_{2}$, hydrogen peroxide; MDA, malondialdehyde; $\mathrm{NO}$, nitric oxide; $\mathrm{O}_{2}{ }^{-}$, superoxide radical; $\mathrm{POD}$, peroxidase; ROS, reactive oxygen species; SNP, sodium nitroprusside; SOD, superoxide dismutase; TCA, trichloroacetic acid

\section{Introduction}

$\mathrm{NaCl}$ stress has recently gained interest in the study of environmental stress on non-halophytic plants. $\mathrm{NaCl}$ stress causes a number of changes in plant metabolism, (1) low water potential, (2) osmotic stress, (3) active oxygen radicals generation $\left(\mathrm{O}_{2} \cdot, \mathrm{OH}\right.$ and $\left.\mathrm{H}_{2} \mathrm{O}_{2}\right)$ and antioxidant enzyme inactivation, (4) ion toxicity (Ons et al., 2012). Reactive oxygen species (ROS) are known to serve as signaling intermediates during biotic and abiotic stresses. ROS can seriously cripple normal metabolism through oxidative damage to lipids, proteins and nucleic acids. Taken together, proline and carbohydrates have accumulated in plant tissues under saline stress, and these substances are suspected of contributing to osmotic adjustment. Recent studies had demonstrated that accumulations of ROS were associated with the antioxidant enzyme system, which has generally been considered to be an adaptive response to the stress condition. 
Antioxidant enzymes, such as superoxide dismutase (SOD), ascorbate peroxidase (APX), peroxidase (POD) and catalase (CAT) can limit or scavenge the generation of ROS. However, high concentrations also cause an imbalance of the cellular ions resulting in ion toxicity, osmotic stress and production of ROS (Cramer et al., 1994). The modulation of the activities of these enzymes may be important in the resistance of plant to environmental stress.

Nitric oxide (NO), a reactive nitrogen species, acts as a signaling molecule with multiple biological functions in plants. NO had been reported to exert a protective effect in response to heavy metal stress (Singh et al., 2008), UV radiation stress (Shi et al., 2005) and disease resistance. Recent data by Zheng et al. (2009) indicated that NO serves as a signal in inducing salt tolerance by increasing the activities of SOD and CAT, decreasing the contents of MDA and the $\mathrm{O}_{2}$. generation rate in the mitochondria. For instance, under salinity condition, the exogenous NO can enhance salt tolerance by stimulating proton-pump activities and $\mathrm{Na}^{+} / \mathrm{H}^{+}$antiport in the tonoplast, and increasing the $\mathrm{K}^{+} / \mathrm{Na}^{+}$ratio (Wang et al., 2009). Although the relationship between NO and ROS has been revealed, it is not a straightforward positive correlation. Therefore, it's urgent to further understand the physiological mechanisms between $\mathrm{NO}$ and $\mathrm{NaCl}$ tolerance, and probe into the methods increasing salinity stress tolerance in plants.

Cotton (Gossypium hirsutum L.) has been considered an important crop for fibre production in several countries. This species can grow well in saline areas, indicating tolerance to salt stresses; however, it is sensitive to salt in the seedling stage (Liu et al., 2013). For taking full advantage of saline soils, the first imperative thing is to enhance the cotton seedling salt-tolerance (Zhang et al., 2011). The aim of this study was to test the hypothesis exogenous application of NO was involved in the acclimation of cotton seedlings to salt stress, by quenching ROS, maintaining ion homeostasis in cells, thus helping to overcome the oxidative damage caused by salt stress.

\section{Materials and Methods}

\subsection{Plant materials and treatment}

Cotton seeds (Gossypium hirsutum L.) were surface sterilized with $2.5 \%$ sodium hypochlorite for 10 min and rinsed thoroughly with distilled water, then germinated on moist filter paper in an incubator at 30 ${ }^{\circ} \mathrm{C}$. The germinated seeds were sown in the washed matrix in the growth chamber $\left(28 / 20{ }^{\circ} \mathrm{C}\right.$; day/night, light intensity $150 \mu \mathrm{mol} \mathrm{m}{ }^{-2} \mathrm{~s}^{-1}, 14$ hours photoperiod, $60 \%$ relative humidity). The cotton seedlings at the second-true leaf stage were watered with one quarterstrength Hoagland nutrient solution. After one week, the seedlings were watered with half-strength Hoagland nutrient solution. Uniformly growing cotton seedlings at the 4-6 true leaf stage were transferred to glassware (Diameter of $15.5 \mathrm{~cm}$, Height of $14 \mathrm{~cm}$ ) filled with Hoagland nutrient solution, and the roots were rinsed with distilled water. At the 6-8 true leaf stage, salinity and $\mathrm{NO}$ treatment were started by adding $\mathrm{NaCl}$ and SNP to the nutrient solution. Culture solution devoid of $\mathrm{NaCl}$ and SNP was served as control. The nutrient solution was adjusted to $\mathrm{pH}$ 6.8. Each of the glassware included 5 seedlings and represented one replicate, and there were three replicates per treatment. The treatment solution was changed everyday to maintain constant $\mathrm{NaCl}$ concentrations. The plants were harvested after 15 days of treatment. The experimental design is provided in Table 1.

\subsection{Plant growth parameters}

The plants were washed with tap water to remove adhering foreign particles. The plants from each treatment were carefully uprooted, and fresh weight (FW), stem height and root length were recorded. The roots were removed, and the individual shoot fresh weight was recorded. The shoots were dried at $80{ }^{\circ} \mathrm{C}$ for $48 \mathrm{~h}$, and their dry weights (DW) were recorded.

The relative growth rate (RGR) was determined using the following formula: [ln (final FW) - $\ln ($ initial FW)]/ days (Baligar et al., 1993). 
Table 1. The experimental design

\begin{tabular}{lll}
\hline Code name & Processing code & Content \\
\hline $\mathrm{CK}$ & $\mathrm{CK}$ & Hoagland nutrient solution contains neither NaCl nor SNP \\
$\mathrm{T} 1$ & $\mathrm{NaCl}$ & Hoagland nutrient solution contains $100 \mathrm{mM} \mathrm{NaCl}$ \\
$\mathrm{T} 2$ & $\mathrm{SNP}_{1}$ & Hoagland nutrient solution contains $0.1 \mathrm{mM} \mathrm{SNP}$ \\
$\mathrm{T} 3$ & $\mathrm{SNP}_{2}$ & Hoagland nutrient solution contains $0.25 \mathrm{mM} \mathrm{SNP}$ \\
$\mathrm{T} 4$ & $\mathrm{NaCl}+\mathrm{SNP}_{1}$ & Hoagland nutrient solution contains both $100 \mathrm{mM} \mathrm{NaCl}$ and $0.1 \mathrm{mMSNP}$ \\
$\mathrm{T} 5$ & $\mathrm{NaCl}+\mathrm{SNP}_{2}$ & Hoagland nutrient solution contains both $100 \mathrm{mM} \mathrm{NaCl}$ and $0.25 \mathrm{mMSNP}$
\end{tabular}

Note: All the treatments in other Tables and Figures (CK and T1 to T5) are in accordance with the descriptions in Table 1

\subsection{Fluorescence parameters, photosynthetic parameters and chlorophyll content}

Young leaves were selected to measure chlorophyll fluorescence by using the pulse amplitude modulated system (model FMS2. Hansatech Instruments. UK) and to measure photosynthetic parameters by using the photosynthesis system (CIRAS-2, UK). They were done between 10:00-11:30 AM.

Young leaves $(0.5 \mathrm{~g}$ of fresh weight) were powdered with liquid nitrogen, and pigments were extracted with 4 volumes of $80 \%(\mathrm{v} / \mathrm{v})$ acetone until complete bleaching. The content of chlorophyll was determined according to Arnon. (1949).

\subsection{Antioxidant enzymes and $\mathrm{O}_{2}$ generation rate extraction and assay}

To extract antioxidant enzymes, leaves were homogenized with $50 \mathrm{mM} \mathrm{Na} 2 \mathrm{HPO}_{4}-\mathrm{NaH}_{2} \mathrm{PO}_{4}$ buffer ( $\mathrm{pH} 7.8$ ) contains $0.2 \mathrm{mM}$ EDTA and $2 \%$ insoluble polyvinylpyrrolidone (PVP) using a chilled mortar and pestle. The homogenate was centrifuged at 12 $000 \times \mathrm{g}$ for $20 \mathrm{~min}$, and the resulting supernatant was used for determination of enzyme activities. The entire extraction procedure was carried out at $4{ }^{\circ} \mathrm{C}$. All spectrophotometric analysis was conducted using a SHIMADZU UV-2450 spectrophotometer (Kyoto, Japan). SOD activity was assayed by measuring its ability to inhibit the photochemical reduction of nitroblue tetrazolium following the method of Tariq et al. (2011). CAT activity was measured as the decline in absorbance at $240 \mathrm{~nm}$ due to the decrease in $\mathrm{H}_{2} \mathrm{O}_{2}$ extinction according to the method of Tariq et al. (2011). POD activity was measured by the increase in absorbance at $470 \mathrm{~nm}$ due to guaiacol oxidation (Zhang et al., 2012).

To measure the $\mathrm{O}_{2}$. - generation rate, $0.3 \mathrm{~g}$ of fresh leaves were ground in liquid $\mathrm{N}_{2}$ and extracted in $3 \mathrm{~mL}$ of icecold $50 \mathrm{mM}$ phosphate buffer solution (PBS) (pH 7.0). The $\mathrm{O}_{2}$. - generation rate was determined by monitoring the $\mathrm{A}_{530}$ of the hydroxylamine reaction following a modified method described by He et al. (2005). A 1-mL aliquot of the supernatant of a fresh leaf extract was added to $0.9 \mathrm{~mL}$ of $65 \mathrm{mM}$ PBS (pH 7.8) and $0.1 \mathrm{~mL}$ of $10 \mathrm{mM}$ hydroxylammonium chloride. The reaction was incubated at $25^{\circ} \mathrm{C}$ for $35 \mathrm{~min}$. A $0.5-\mathrm{mL}$ aliquot of the solution from the reaction mixture described above was then added to $0.5 \mathrm{~mL}$ of $17 \mathrm{mM}$ sulfonic acid and $0.5 \mathrm{~mL}$ of $7.8 \mathrm{mM}$ a-naphthylamine solution. After a 20 -min reaction, $2 \mathrm{~mL}$ of ether was added and mixed well. The solution was centrifuged at $1500 \times \mathrm{g}$ at $4{ }^{\circ} \mathrm{C}$ for $5 \mathrm{~min}$. The absorbance of the pink supernatant was measured at $530 \mathrm{~nm}$ with a spectrophotometer. The absorbance values were calibrated to a standard curve generated with known concentrations of $\mathrm{HNO}_{2}$.

\subsection{Determination of lipid peroxidation}

Lipid peroxidation was determined by measuring MDA, a major TBARS and products of lipid peroxidation. Samples $(0.2 \mathrm{~g})$ were ground in $3 \mathrm{~mL}$ of 
trichloroacetic acid $(0.1 \%, \mathrm{w} / \mathrm{v})$. The homogenate was centrifuged at $10000 \times \mathrm{g}$ for $10 \mathrm{~min}$, and $1 \mathrm{~mL}$ of the supernatant fraction was mixed with $4 \mathrm{~mL}$ of $0.5 \%$ thiobarbituric acid (TBA) in 20\% TCA. The mixture was heated at $95^{\circ} \mathrm{C}$ for $30 \mathrm{~min}$, chilled on ice, and then centrifuged at $10000 \times \mathrm{g}$ for $5 \mathrm{~min}$. The absorbance of the supernatant was measured at $532 \mathrm{~nm}$. The value for non-specific absorption at $600 \mathrm{~nm}$ was subtracted.

\subsection{Proline content assay}

Proline accumulation was determined as described by Bates et al. (1973). $0.5 \mathrm{~g}$ of fresh leaf tissues from each treatment were homogenized in $10 \mathrm{~mL}$ of $3 \% \mathrm{w} / \mathrm{v}$ sulphosalicylic acid and the homogenate was filtrated. The resulting solution was treated with $2.5 \%$ ninhidrine solution and glacial acetic acid. In test tubes, the reaction mixtures were kept in a water bath at $100{ }^{\circ} \mathrm{C}$ for $60 \mathrm{~min}$ to develop the colors. Soon after removal from the water bath, the test tubes were cooled in ice bath and toluene was added to separate chromophores. Optical density was read at 520 $\mathrm{nm}$ using UV-VIS spectrophotometer. The proline concentration was determined from a standard curve and calculated on a fresh weight basis ( $\mu$ g proline $\mathrm{g}^{-1}$ of fresh weight material).

\subsection{Nitrate reductase (NR) activity assay}

NR activity was measured according to Yaneva et al. (2002). Leaf segments were homogenized in a medium containing $5 \mathrm{mM}$ EDTA, $5 \mathrm{mM} \mathrm{GSH}, 1 \%(\mathrm{w} / \mathrm{v})$ casein, $0.1 \%(\mathrm{w} / \mathrm{v})$ insoluble PVP and $50 \mathrm{mM}$ HEPES $\mathrm{pH} 7.5$ and centrifuged for $15 \mathrm{~min}$ at $17000 \times \mathrm{g}$. The assay mixture for measuring NR activity contained $200 \mu \mathrm{mol}$ $\mathrm{KNO}_{3}, 0.2 \mu \mathrm{mol} \mathrm{NADH}$ and $100 \mu \mathrm{L}$ of the homogenate. After incubation at $30^{\circ} \mathrm{C}$ for $20 \mathrm{~min}$, the reaction was stopped by the addition of $50 \mu \mathrm{L} 1 \mathrm{M}$ zinc acetate. The mixture was centrifuged $5 \mathrm{~min}$ at $7000 \times \mathrm{g}$ and the supernatant was used to determine nitrite production by reading the absorbance at $540 \mathrm{~nm}$ after the addition of $1 \%$ sulphanilamide in $1.5 \mathrm{M} \mathrm{HCl}$ and $0.01 \% \mathrm{~N}-(1-$ naphthyl)-ethylenediammonium dichloride.

\section{8. $\mathrm{Na}^{+}, \mathrm{K}^{+}, \mathrm{Ca}^{2+}$ and $\mathrm{Mg}^{2+}$ contents assay}

For the determination of $\mathrm{Na}^{+}, \mathrm{K}^{+}, \mathrm{Ca}^{2+}$ and $\mathrm{Mg}^{2+}$ concentrations, powdered dried sample mixtures were digested in an acid mixture $\left(\mathrm{HNO}_{3}-\mathrm{HClO}_{4}\right.$ [3:1]) and briefly centrifuged. $\mathrm{Na}^{+}, \mathrm{K}^{+}, \mathrm{Ca}^{2+}$ and $\mathrm{Mg}^{2+}$ concentrations were determined using an atomic absorption spectrophotometer (SHIMADZU AA6300, Kyoto, Japan).

\subsection{Statistical analysis}

Excel 2003 software was used to process data and construct the tables, the SPSS software (SPSS 17.0) was used for statistical analysis, and the least significant difference (LSD) was calculated to compare the differences between means in each treatment. Means followed by different letters are statistically significant at $p \leq 0.05$.

\section{Results}

\subsection{Plant growth parameters}

$\mathrm{NaCl}$ stress had a strong impact on plant growth. RGR, stem height and root length exhibited significant decreases in the cotton treated with $\mathrm{NaCl}$ (Table 2). However, root/shoot had no significantly difference. Compared with CK and SNP treatment, RGR, stem length and root length decreased (by $30.02 \%, 11.28 \%$, $10.79 \%$ ), and their decrement extent under $0.1 \mathrm{mM}$ concentration were less than under $0.25 \mathrm{mM}$ concentration.

\subsection{Fluorescence parameters, photosynthetic parameters and chlorophyll Content}

Photosynthesis system is sensitive to environmental stress. The chlorophyll content and stomatal conductance had been proved to be key limiting factors on photosynthesis. Both Pn and Tr exhibited amelioration treated with SNP in the presence or absence of $\mathrm{NaCl}$ stress (Table 3). Increases in Pn and $\operatorname{Tr}(52.12 \%, 14.29 \%)$ occurred in $\mathrm{T} 2$. But a decrease 
in $\mathrm{Pn}$ and $\operatorname{Tr}(13.60 \%, 4.76 \%)$ occurred in $\mathrm{T} 4$ (Table $3)$. The decrease in $\mathrm{Ci}(2.26 \%)$ occurred in the $\mathrm{NaCl}$
stress.Treatment of $0.1 \mathrm{mM}$ SNP and $\mathrm{NaCl}$ stress caused a significant increase in $\mathrm{Ci}(1.66 \%)$.

Table 2. Effects of $\mathrm{NaCl}$ and SNP on the growth attributes in cotton seedlings.

\begin{tabular}{ccccc}
\hline Treatment & RGR $\left(\mathrm{g} \mathrm{day}^{-1}\right)$ & Stem height $\left(\mathrm{cm} \mathrm{plant}^{-1}\right)$ & Root length $\left(\mathrm{cm} \mathrm{plant}^{-1}\right)$ & Root/shoot \\
\hline CK & $0.35 \pm 0.04 \mathrm{a}$ & $12.77 \pm 0.25 \mathrm{a}$ & $11.77 \pm 0.25 \mathrm{~b}$ & $0.15 \pm 0.02 \mathrm{c}$ \\
T1 & $0.19 \pm 0.22 \mathrm{c}$ & $9.67 \pm 0.35 \mathrm{c}$ & $10.43 \pm 0.40 \mathrm{c}$ & $0.29 \pm 0.01 \mathrm{a}$ \\
T2 & $0.41 \pm 0.05 \mathrm{a}$ & $13.33 \pm 0.29 \mathrm{a}$ & $8.17 \pm 0.29 \mathrm{e}$ & $0.19 \pm 0.01 \mathrm{~b}$ \\
T3 & $0.28 \pm 0.03 \mathrm{~b}$ & $11.33 \pm 0.29 \mathrm{~b}$ & $9.40 \pm 0.40 \mathrm{~d}$ & $0.21 \pm 0.01 \mathrm{~b}$ \\
T4 & $0.27 \pm 0.41 \mathrm{~b}$ & $11.33 \pm 0.76 \mathrm{~b}$ & $10.50 \pm 0.87 \mathrm{c}$ & $0.28 \pm 0.02 \mathrm{a}$ \\
T5 & $0.15 \pm 0.08 \mathrm{c}$ & $7.67 \pm 0.29 \mathrm{~d}$ & $14.23 \pm 0.64 \mathrm{a}$ & $0.21 \pm 0.03 \mathrm{~b}$ \\
\hline
\end{tabular}

Note: Values represent the mean \pm S.D. $(\mathrm{n}=3)$. Different lowercase letters indicate significant differences at $p<0.05$.

Table 3. Effects of $\mathrm{NaCl}$ and SNP treatments on fluorescence parameters and photosynthetic parameters in cotton leaves.

\begin{tabular}{ccccccc}
\hline Treatment & $\begin{array}{c}\text { Net photosynthetic } \\
\text { rate } P n \\
\left(\mu \mathrm{mol} \mathrm{m}^{-2} \mathrm{~s}^{-1}\right)\end{array}$ & $\begin{array}{c}\text { Intercellular } \mathrm{CO}_{2} \\
\text { concentration }(\mathrm{Ci}) \\
\left(\mu \mathrm{mol} \mathrm{mol}^{-1}\right)\end{array}$ & $\begin{array}{c}\text { Transpiration } \\
\text { rate } T r \\
\left(\mathrm{mmol} \mathrm{m}^{-2} \mathrm{~s}^{-1}\right)\end{array}$ & $\begin{array}{c}\text { Photosystem II } \\
(\mathrm{PS} \mathrm{II})\end{array}$ & $\begin{array}{c}\text { PSII maximum light } \\
\text { energy transformation } \\
(\mathrm{Fv} / \mathrm{Fm})\end{array}$ & $\begin{array}{c}\text { PSII Activity } \\
(\mathrm{Fv} / \mathrm{Fo})\end{array}$ \\
\hline CK & $2.59 \pm 0.05 \mathrm{~b}$ & $699.13 \pm 2.84 \mathrm{e}$ & $0.21 \pm 0.01 \mathrm{~b}$ & $0.35 \pm 0.02 \mathrm{~b}$ & $0.81 \pm 0.01 \mathrm{bc}$ & $4.32 \pm 0.02 \mathrm{~d}$ \\
T1 & $0.83 \pm 0.01 \mathrm{f}$ & $732.23 \pm 2.03 \mathrm{~b}$ & $0.16 \pm 0.01 \mathrm{e}$ & $0.29 \pm 0.01 \mathrm{c}$ & $0.74 \pm 0.14 \mathrm{~d}$ & $3.28 \pm 0.11 \mathrm{f}$ \\
T2 & $3.94 \pm 0.06 \mathrm{a}$ & $683.33 \pm 2.49 \mathrm{f}$ & $0.24 \pm 0.01 \mathrm{a}$ & $0.53 \pm 0.02 \mathrm{a}$ & $0.82 \pm 0.01 \mathrm{~b}$ & $4.41 \pm 0.01 \mathrm{c}$ \\
T3 & $2.06 \pm 0.04 \mathrm{~d}$ & $714.80 \pm 0.56 \mathrm{c}$ & $0.18 \pm 0.02 \mathrm{~d}$ & $0.52 \pm 0.01 \mathrm{a}$ & $0.81 \pm 0.02 \mathrm{bc}$ & $4.55 \pm 0.01 \mathrm{~b}$ \\
T4 & $2.28 \pm 0.04 \mathrm{c}$ & $710.73 \pm 0.38 \mathrm{~d}$ & $0.20 \pm 0.01 \mathrm{c}$ & $0.36 \pm 0.01 \mathrm{~b}$ & $0.84 \pm 0.02 \mathrm{a}$ & $5.03 \pm 0.01 \mathrm{a}$ \\
T5 & $1.38 \pm 0.24 \mathrm{e}$ & $744.87 \pm 1.07 \mathrm{a}$ & $0.16 \pm 0.02 \mathrm{e}$ & $0.31 \pm 0.01 \mathrm{c}$ & $0.80 \pm 0.20 \mathrm{c}$ & $4.07 \pm 0.02 \mathrm{e}$ \\
\hline
\end{tabular}

Note: Values represent the mean \pm S.D. $(n=3)$. Different lowercase letters indicate significant differences at $p<0.05$.

As shown in Table 3, compared with CK, PSII, $\mathrm{Fv} / \mathrm{Fm}$ and $\mathrm{Fv} / \mathrm{Fo}$ exposed $\mathrm{NaCl}$ were reduced significantly (by $17.14 \%, 8.64 \%$ and $24.07 \%$ ). Different concentrations of SNP under normal growth condition could improve PSII, Fv/Fm and Fv/Fo.

$\mathrm{NaCl}$ stress resulted in the usually observed decrease in chlorophyll content (Table 4). However, a significant increase in chlorophyll content was seen in the leaves treated with SNP and $\mathrm{NaCl}$. Treatments with $100 \mathrm{mM} \mathrm{NaCl}, 0.1 \mathrm{mM}$ SNP, $100 \mathrm{mM} \mathrm{NaCl}$ and $0.1 \mathrm{mM}$ SNP all resulted in significant increases in carotenoids. However, the increase observed in T5 was lower $(8.47 \%)$ than CK.

\subsection{Antioxidative enzyme activities}

Results showed that $\mathrm{NaCl}$ stress could be an influential component of environmental stress on cotton (Table 5). 
6 Dong et al.

Table 4. Effects of $\mathrm{NaCl}$ and $\mathrm{SNP}$ treatments on chlorophyll contents in cotton leaves.

\begin{tabular}{cccccc}
\hline Treatment & Chla $\left(\mathrm{mg} \mathrm{kg}^{-1}\right)$ & Chl $\mathrm{b}\left(\mathrm{mg} \mathrm{kg}^{-1}\right)$ & Chl $\mathrm{a} / \mathrm{b}$ & Chl a+b $\left(\mathrm{mg} \mathrm{kg}^{-1}\right)$ & Carotenoids $\left(\mathrm{mg} \mathrm{kg}^{-1}\right)$ \\
\hline CK & $0.85 \pm 0.15 \mathrm{~b}$ & $0.41 \pm 0.11 \mathrm{ab}$ & $2.12 \pm 0.21 \mathrm{c}$ & $1.25 \pm 0.04 \mathrm{~b}$ & $0.14 \pm 0.02 \mathrm{~b}$ \\
T1 & $0.68 \pm 0.23 \mathrm{~b}$ & $0.30 \pm 0.11 \mathrm{bc}$ & $2.30 \pm 0.04 \mathrm{bc}$ & $0.95 \pm 0.01 \mathrm{~d}$ & $0.14 \pm 0.03 \mathrm{~b}$ \\
T2 & $1.23 \pm 0.16 \mathrm{a}$ & $0.52 \pm 0.07 \mathrm{a}$ & $2.36 \pm 0.02 \mathrm{~b}$ & $1.68 \pm 0.15 \mathrm{a}$ & $0.22 \pm 0.04 \mathrm{a}$ \\
T3 & $0.82 \pm 0.09 \mathrm{~b}$ & $0.35 \pm 0.03 \mathrm{bc}$ & $2.33 \pm 0.01 \mathrm{bc}$ & $1.10 \pm 0.04 \mathrm{c}$ & $0.15 \pm 0.02 \mathrm{~b}$ \\
T4 & $0.80 \pm 0.20 \mathrm{~b}$ & $0.33 \pm 0.07 \mathrm{bc}$ & $2.45 \pm 0.10 \mathrm{ab}$ & $1.13 \pm 0.02 \mathrm{c}$ & $0.16 \pm 0.04 \mathrm{~b}$ \\
T5 & $0.64 \pm 0.02 \mathrm{~b}$ & $0.24 \pm 0.03 \mathrm{c}$ & $2.67 \pm 0.23 \mathrm{a}$ & $0.87 \pm 0.01 \mathrm{e}$ & $0.13 \pm 0.05 \mathrm{~b}$ \\
\hline
\end{tabular}

Note: Values represent the mean \pm S.D. $(n=3)$. Different lowercase letters indicate significant differences at $p<0.05$.

Table 5. Effects of $\mathrm{NaCl}$ and $\mathrm{SNP}$ treatments on the $\mathrm{SOD}$ activity, $\mathrm{POD}$ activity, CAT activity, $\mathrm{O}_{2}{ }^{-}$generation rate, the content of MDA and proline content in leaves of cotton seedlings.

\begin{tabular}{ccccccc}
\hline Treatment & $\begin{array}{c}\text { SOD activity } \\
\left(\mathrm{U} \mathrm{g}^{-1} \mathrm{FW}\right)\end{array}$ & $\begin{array}{c}\text { POD activity } \\
\left(\mathrm{U} \mathrm{g}^{-1} \mathrm{~min}^{-1} \mathrm{FW}\right)\end{array}$ & $\begin{array}{c}\text { CAT activity } \\
\left(\mu \mathrm{mol} \mathrm{H}_{2} \mathrm{O}_{2} \mathrm{mg}^{-1}\right. \\
\left.\mathrm{min}^{-1} \mathrm{FW}\right)\end{array}$ & $\begin{array}{c}\mathrm{O}_{2}-\text { generation rate } \\
\left(\mu \mathrm{mol} \cdot \mathrm{g}^{-1} \cdot \mathrm{h}^{-1} \mathrm{FW}\right)\end{array}$ & $\begin{array}{c}\text { MDA content } \\
\left(\mu \mathrm{mol} \cdot \mathrm{g}^{-1} \mathrm{FW}\right)\end{array}$ & $\begin{array}{c}\text { Proline } \\
\text { content } \\
\left(\mu \mathrm{g} \mathrm{g} \mathrm{FW}^{-1}\right.\end{array}$ \\
\hline $\mathrm{CK}$ & $257.36 \pm 13.38 \mathrm{~d}$ & $255.33 \pm 18.63 \mathrm{c}$ & $1.13 \pm 0.12 \mathrm{e}$ & $0.83 \pm 0.01 \mathrm{c}$ & $0.0024 \pm 0.0002 \mathrm{~d}$ & $9.64 \pm 1.48 \mathrm{~d}$ \\
$\mathrm{~T} 1$ & $362.26 \pm 8.44 \mathrm{~b}$ & $510.17 \pm 21.77 \mathrm{a}$ & $3.51 \pm 0.12 \mathrm{bc}$ & $1.21 \pm 0.12 \mathrm{~b}$ & $0.0059 \pm 0.0012 \mathrm{~b}$ & $14.39 \pm 0.68 \mathrm{c}$ \\
$\mathrm{T} 2$ & $384.42 \pm 12.13 \mathrm{~b}$ & $396.93 \pm 24.08 \mathrm{~b}$ & $1.76 \pm 0.08 \mathrm{~d}$ & $0.95 \pm 0.04 \mathrm{c}$ & $0.0033 \pm 0.0003 \mathrm{c}$ & $16.86 \pm 0.66 \mathrm{~b}$ \\
$\mathrm{~T} 3$ & $328.08 \pm 2.60 \mathrm{c}$ & $407.86 \pm 60.51 \mathrm{~b}$ & $2.52 \pm 0.73 \mathrm{c}$ & $1.14 \pm 0.10 \mathrm{~b}$ & $0.0062 \pm 0.0010 \mathrm{~b}$ & $6.08 \pm 0.52 \mathrm{e}$ \\
$\mathrm{T} 4$ & $419.9720 .14 \mathrm{a}$ & $396.91 \pm 45.53 \mathrm{~b}$ & $4.11 \pm 0.18 \mathrm{a}$ & $0.91 \pm 0.01 \mathrm{c}$ & $0.0045 \pm 0.0005 \mathrm{c}$ & $32.03 \pm 1.78 \mathrm{a}$ \\
$\mathrm{T} 5$ & $260.90 \pm 22.18 \mathrm{~d}$ & $459.87 \pm 36.88 \mathrm{ab}$ & $2.69 \pm 0.19 \mathrm{c}$ & $1.39 \pm 0.04 \mathrm{a}$ & $0.0075 \pm 0.0012 \mathrm{a}$ & $16.77 \pm 0.82 \mathrm{~b}$ \\
\hline
\end{tabular}

Note: Values represent the mean \pm S.D. $(n=3)$. Different lowercase letters indicate significant differences at $p<0.05$.

An increase in SOD activity was observed under $\mathrm{NaCl}$ stress. Adding SNP further increased the SOD activity. Compared with CK, the SOD activity of T1 was increased by $40.76 \%$. Table 5 showed that SOD activity was increased by $63.18 \%$ and $1.38 \%$ under $\mathrm{T} 4$ and T5, respectively. POD activity also showed an increase under $\mathrm{NaCl}$ treatment (Table 5). 65.46\% and $93.13 \%$ increase was observed with $\mathrm{T} 2$ and $\mathrm{T} 4$. However, $0.25 \mathrm{mM}$ SNP caused a decrease in activity under $\mathrm{NaCl}$ stress. $\mathrm{NaCl}$ stress also decreased CAT activity. A $210.62 \%$ decline was observed under $\mathrm{NaCl}$ stress compared with $\mathrm{CK}$. SNP treatment could partially ameliorate the toxic effect of $\mathrm{NaCl}$ treatment on CAT activity. $0.1 \mathrm{mM}$ SNP was more effective in increasing the CAT activity.

\subsection{Superoxide anions $\left(\mathrm{O}_{2}{ }^{-}{ }^{-}\right)$generation rate and lipid peroxidation}

Whether NO is protective or toxic to plants is found to 
be quite concentration dependent. Low concentration of SNP $(0.1 \mathrm{mM})$ could inhibit the $\mathrm{O}_{2}$. ${ }^{-}$generation rate and reduce MDA content, while high concentration $(0.25$ $\mathrm{mM}$ ) of SNP had opposite effects (Table 5). The $\mathrm{O}_{2}$. generation rate under $\mathrm{NaCl}$ stress increased to $45.78 \%$ compared with CK while it increased to $14.60 \%$ and $36.68 \%$ in the presence of the two concentrations of SNP alone. But there was no pronounced difference between $\mathrm{CK}$ and $0.1 \mathrm{mM}$ SNP under $\mathrm{NaCl}$ stress.

MDA is an indicator of lipid peroxidation and oxidative damage to membrane. The results reported here (Table 5) showed that the accumulation of MDA was higher in $\mathrm{NaCl}$ treatment in cotton leaves, and the increase was remarkably prevented in the $0.1 \mathrm{mM}$ SNP treatment. However, increments of MDA were more severe under $0.25 \mathrm{mM}$ SNP treatment no matter under normal growth condition or under $\mathrm{NaCl}$ stress condition.

\subsection{Proline content}

Table 5 showed that a large number of proline would be accumulated under $\mathrm{NaCl}$ stress. Meanwhile, proline of $0.1 \mathrm{mM} \mathrm{SNP}$ and $\mathrm{NaCl}$ treatment accumulated more than others. Compared with CK, proline content in T1 was increased by $49.31 \%$. Under normal condition, by adding $0.1 \mathrm{mM} \mathrm{SNP}$, the content increased by $74.96 \%$ of CK. While T5 increased proline accumulation in leaves by $122.57 \%$ than only $\mathrm{NaCl}$ treated.

\subsection{Nitrate reductase activity}

In cotton plants grown with T4, NR activity showed the maximum activity (Figure 1). In addition, SNP supply affected leaf NR activity since leaf NR activity in cotton plants treated with $100 \mathrm{mM} \mathrm{NaCl}$ was lower than that in plants treated with $0.1 \mathrm{mM}$ and $0.25 \mathrm{mM}$ SNP. These results supported the idea that $\mathrm{NaCl}$ was negative for NR activity and the SNP was positive for NR activity.

\section{7. $\mathrm{Na}^{+}, \mathrm{K}^{+}, \mathrm{Ca}^{2+}$, and $\mathrm{Mg}^{2+}$ contents}

As shown in Figure 2, $\mathrm{Na}^{+}$concentration in dry leaves was increased under $\mathrm{NaCl}$ stress. Conversely, $\mathrm{K}^{+}$content in $\mathrm{CK}$ was relatively high, but decreased under $\mathrm{NaCl}$ stress.

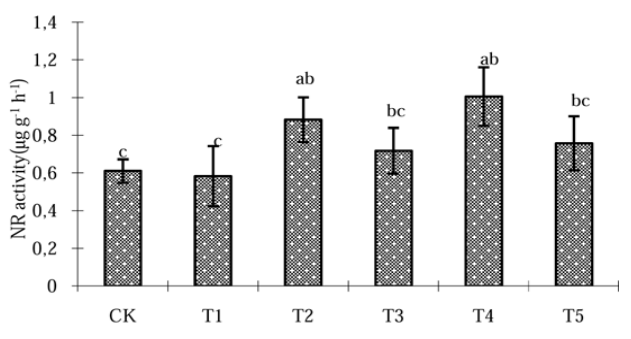

Figure 1. Effects of $\mathrm{NaCl}$ and SNP treatments on the nitrate reductase activity in cotton seedlings. Note: Values represent the mean \pm S.D. $(n=3)$. Different lowercase letters indicate significant differences at $p$ $<0.05$.

SNP treatment decreased $\mathrm{Na}^{+}$concentration, but increased $\mathrm{K}^{+}$concentration under $\mathrm{NaCl}$ stress in cotton leaves. $\mathrm{Na}^{+}$concentrations in the root and stem under the $0.1 \mathrm{mM}$ SNP treatment were decreased by $62.17 \%$ and $9.17 \%$ (Figure $2 \mathrm{a}$ ). $\mathrm{K}^{+}$ concentration in the leaf under T3 was increased by $95.61 \%$ (Figure $2 \mathrm{~b}$ ), compared with $\mathrm{T} 1$. After 15 days of $100 \mathrm{mM} \mathrm{NaCl}$ stress, $\mathrm{Ca}^{2+}$ and $\mathrm{Mg}^{2+}$ contents decreased significantly in both, but the cotton treated with $\mathrm{T} 5$ accumulated more $\mathrm{Ca}^{2+}$ and $\mathrm{Mg}^{2+}$ than treated with $\mathrm{NaCl}$ (Figure 2c-d).

As shown in Table 6, the seedlings with root, stem and leaves exposed to $100 \mathrm{mM} \mathrm{NaCl}$ had a marked increase in $\mathrm{Na}^{+} / \mathrm{K}^{+}$ratio (by $12.42,11.60,19.64$ times, respectively) and had a signally decrease in $\mathrm{Ca}^{2+} / \mathrm{Na}^{+}$ratio (by $94.55 \%, 75.62 \%, 95.21 \%$, respectively). Therefore, we examined the effects of SNP on the content of the $\mathrm{Na}^{+} / \mathrm{K}^{+}$and $\mathrm{Ca}^{2+} / \mathrm{Na}^{+}$ratio under $\mathrm{NaCl}$ stress. We found SNP led to a lower $\mathrm{Na}^{+} / \mathrm{K}^{+}$ratio and an upper $\mathrm{Ca}^{2+} / \mathrm{Na}^{+}$ratio under $\mathrm{NaCl}$ stress. These results further suggest that the SNP has an effectively function in the regulation of ionic balance under $\mathrm{NaCl}$ stress. 
b
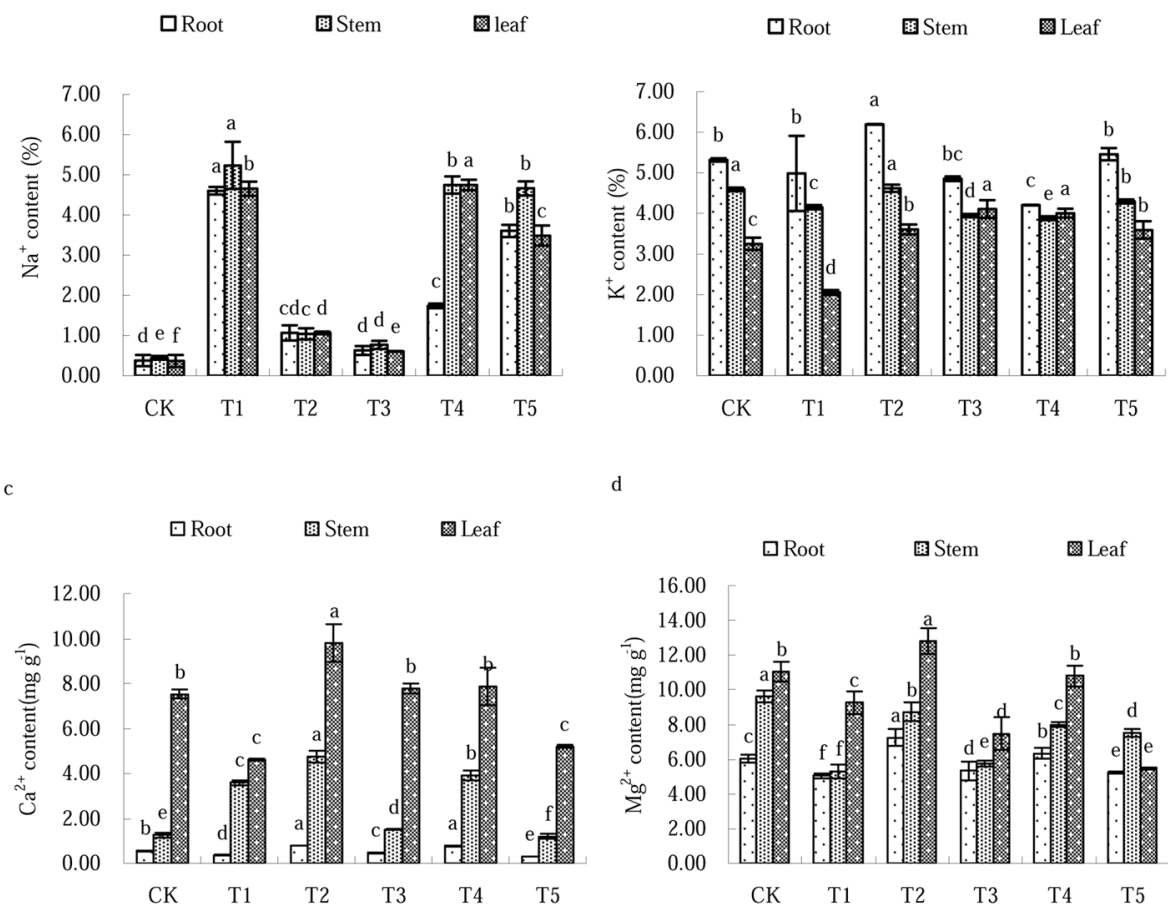

d

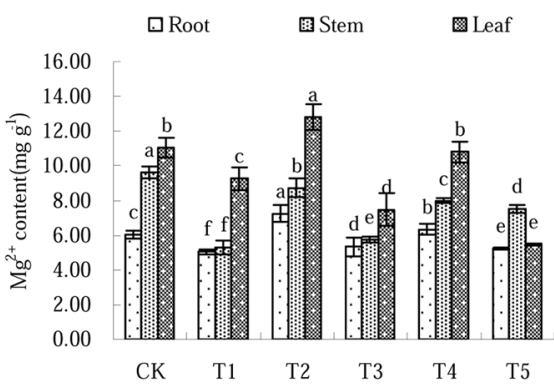

Figure 2. Effects of $\mathrm{NaCl}$ and $\mathrm{SNP}$ treatments on the content of $\mathrm{Na}^{+}(\mathrm{a}), \mathrm{K}^{+}(\mathrm{b}), \mathrm{Ca}^{2+}$ (c) and $\mathrm{Mg}^{2+}$ (d) in cotton seedlings. Note: Values represent the mean \pm S.D. $(n=3)$. Different lowercase letters indicate significant differences at $p<0.05$.

\section{Discussion}

The results showed that the ROS level increased significantly when the NaCl-tolerant cotton was subjected to $\mathrm{NaCl}$ and the level of ROS generated was limited in the presence of $\mathrm{NO}$. Under $\mathrm{NaCl}$ stress, the RGR of cotton seedlings suffered different degrees of inhibition under different treatment (Table 2). Under salt condition, we not only found that SNP caused enhancement in plant growth, but also found enhancement in stem and root length. Hence, it may be the strong evidence that $\mathrm{NO}$ is involved in the plant growth increasing osmotic pressure of the cell and improving the cytoplasmics viscosity. However, high concentration of SNP inhibited the growth of cotton seedlings.

Most recently, it was reported that an appropriate concentration of NO could improve photosynthesis, fluorescence parameters and chlorophyll content. In this research, $100 \mathrm{mM} \mathrm{NaCl}$ could restrain chlorophyll synthetic, reduce photosynthetic efficiency and transpiration rate. However, SNP supplementation could alleviate the adverse effects (Table 3, Table 4). 
Table 6. Effects of $\mathrm{NaCl}$ and SNP treatments on the $\mathrm{Na}^{+} / \mathrm{K}^{+}, \mathrm{Ca}^{+} / \mathrm{Na}^{+}$of root, stem and leaf in cotton seedlings.

\begin{tabular}{ccccccc}
\hline \multirow{2}{*}{ Treatment } & \multicolumn{3}{c}{$\mathrm{Na}^{+} / \mathrm{K}$} & \multicolumn{3}{c}{$\mathrm{Ca}^{2+} / \mathrm{Na}$} \\
\cline { 2 - 7 } & Root & Shoot & Leaf & Root & Shoot & Leaf \\
\hline CK & $0.07 \pm 0.01 \mathrm{~d}$ & $0.10 \pm 0.01 \mathrm{f}$ & $0.11 \pm 0.01 \mathrm{e}$ & $1.47 \pm 0.05 \mathrm{a}$ & $2.83 \pm 0.30 \mathrm{~b}$ & $20.65 \pm 0.36 \mathrm{a}$ \\
T1 & $0.94 \pm 0.17 \mathrm{a}$ & $1.26 \pm 0.01 \mathrm{a}$ & $2.27 \pm 0.07 \mathrm{a}$ & $0.08 \pm 0.01 \mathrm{c}$ & $0.69 \pm 0.01 \mathrm{de}$ & $0.99 \pm 0.01 \mathrm{~d}$ \\
T2 & $0.17 \pm 0.01 \mathrm{~d}$ & $0.23 \pm 0.03 \mathrm{e}$ & $0.30 \pm 0.02 \mathrm{~d}$ & $0.74 \pm 0.01 \mathrm{bc}$ & $4.62 \pm 0.66 \mathrm{a}$ & $9.17 \pm 0.80 \mathrm{c}$ \\
T3 & $0.13 \pm 0.01 \mathrm{~d}$ & $0.19 \pm 0.01 \mathrm{~b}$ & $0.15 \pm 0.01 \mathrm{e}$ & $0.74 \pm 0.01 \mathrm{bc}$ & $1.97 \pm 0.03 \mathrm{c}$ & $12.90 \pm 0.34 \mathrm{~b}$ \\
T4 & $0.41 \pm 0.28 \mathrm{c}$ & $1.22 \pm 0.02 \mathrm{~b}$ & $1.18 \pm 0.04 \mathrm{~b}$ & $0.89 \pm 1.00 \mathrm{ab}$ & $0.83 \pm 0.01 \mathrm{~d}$ & $1.66 \pm 0.18 \mathrm{~d}$ \\
T5 & $0.66 \pm 0.01 \mathrm{~b}$ & $1.09 \pm 0.07 \mathrm{c}$ & $0.97 \pm 0.01 \mathrm{c}$ & $0.08 \pm 0.01 \mathrm{c}$ & $0.26 \pm 0.01 \mathrm{e}$ & $1.49 \pm 0.03 \mathrm{~d}$ \\
\hline
\end{tabular}

Note: Values represent the mean \pm S.D. $(\mathrm{n}=3)$. Different lowercase letters indicate significant differences at $p<0.05$.

In addition, $\mathrm{NaCl}$ also increased stomatal resistance and $\mathrm{Ci}$, and decreased $\mathrm{Pn}$. Low photosynthetic pigment or high $\mathrm{Na}^{+}$content could inhibit $\mathrm{Mg}^{2+}$ absorbing and restrain chlorophyll synthesis (Li et al., 2011), it possibly due to too much $\mathrm{Na}^{+}$inhibited protein synthesis, weakened the links of chlorophyll and chloroplastin, and led to chlorophyll decomposing. (Corpas et al., 2006) suggested that adding appropriate SNP could really alleviate salt toxicity though improving the plant photosynthesis.

The ratio $\mathrm{Fv} / \mathrm{Fm}$ is proportional within a similar range, 0.76 to 0.85 , to normal conditions. Yet the ratio decreased under stress (Liang et al., 2010). Thus, this parameter was often used to evaluate the photoinhibition and the damage of PSII complex. Results showed that $\mathrm{NaCl}$ stress induced a decrease of $\mathrm{Fv} / \mathrm{Fm}$ and $\mathrm{Fv} / \mathrm{Fo}$, which indicated the destruction or inactivation of PSII reaction center. However, SNP supplementation alleviated the effect. PSII plays an especially important role in the response of photosynthesis in higher plants to environmental perturbations and stresses. The relationship between PSII and photosynthetic $\mathrm{CO}_{2}$ assimilation is examined and factors identified that may modulate PSII activity in vivo. Thus, it can be inferred that apart from a signaling molecule, SNP supplement may act as a stress factor in promoting photosynthesis.
As for the possible role of $\mathrm{NO}$ in the $\mathrm{NaCl}$-induced upregulation of antioxidant enzyme activity, the addition of NO to the media in the absence of salt stress resulted in an increase in antioxidant enzyme activity. The same results were observed in the present studies point towards its induction to quench higher levels of superoxide radical generated due to $\mathrm{NaCl}$ stress. Salt stress, like another abiotic stress, can lead to oxidative stress through the increase in ROS, which can potentiate the accumulation of MDA, an indicator of salt-induced oxidative damage to the membranes. Therefore, we deduced that the protective role of SNP might be related to its effects on the elimination of MDA. As such, this experiment suggested SNP could partially alleviate the toxic effect of $\mathrm{NaCl}$ on $\mathrm{O}_{2}$ - generation rate. However, the high concentration of SNP could make SOD, POD and CAT activity decrease, and MDA content increase, which may be due to high concentration of SNP interactions with $\mathrm{O}_{2}$. , and generate a large number of peroxynitrite anion. The peroxynitrite anion form peroxynitrite with strong oxidizing, which can destroy the structure and function of biological macromolecules (Zhang et al., 2004).

Proline plays important roles on clearance of ROS, improvement of the antioxidant capacity, adjustment of osmotic substances and stability of the structure of biological macromolecules. 
This study showed that $\mathrm{NaCl}$ stress increased the proline accumulation, and SNP supplement could further induce the proline accumulation. Proline can protect plants from free-radical induced damage by quenching of singlet oxygen (Matysik et al., 2002). SNP treatment increased proline content to scavenge the elevated level of ROS and increased the antioxidase activity in this study.

A key step in nitrate assimilation is the reduction of this anion to nitrite in the reaction catalyzed by NR, an enzyme that is highly regulated at the transcriptional and post-transcriptional levels (Kaiser, 2001). NR has been studied extensively as a key enzyme of nitrogen metabolism. The involvement of NO in the activation of NR activity has been reported recently in leaves of wheat (Rosales et al., 2012), where NR activity was significantly enhanced by the addition of SNP. In concordance with these results, NR activity was significantly stimulated by $0.1 \mathrm{mM}$ SNP in our experimental conditions. All these results indicate that endogenous NO is indispensable and important for enhancing NR activity. But Xiong (2009) study reported that treatment with SNP had no observable effect on NR activity. In order to prove the true theory, further research is required.

Ionic imbalance in plants is mainly caused by the influx of excess $\mathrm{Na}^{+}$. It is the essential condition of maintaining the cytoplasm enzyme activity through maintaining low $\mathrm{Na}^{+}$and high $\mathrm{K}^{+}$(Wang et al., 2011). Yamamoto (2011) showed that salt-tolerance of plant is concerned with low absorption and accumulation in $\mathrm{Na}$. So if growing in $\mathrm{Na}^{+}$excessive environment, the plant could lack $\mathrm{K}^{+}$, and restrain the absorption of $\mathrm{Ca}^{2+}, \mathrm{Mg}^{2+}$ as well. Under $\mathrm{NaCl}$ stress, the content of inorganic ions in cotton seedlings changed markedly (Figure 2), with $\mathrm{Na}^{+}$showing increased levels and $\mathrm{K}^{+}, \mathrm{Ca}^{+}, \mathrm{Mg}^{2+}$ showing decreased levels. The result was same with Kapila's result (Kapila et al., 2010). However, adding the appropriate concentration of SNP could reduce $\mathrm{Na}^{+}$absorption and promote $\mathrm{K}^{+}, \mathrm{Mg}^{2+}$, $\mathrm{Ca}^{2+}$ absorption significantly, which may be the reason that $\mathrm{NO}$ serves as a signal in inducing $\mathrm{NaCl}$ tolerance by increasing $\mathrm{K}^{+} / \mathrm{Na}^{+}$through increasing expression of PM $\mathrm{H}^{+}$-ATPase activity. In addition, the protective effect of SNP on $\mathrm{NaCl}$ stress might be related to its increase osmotic regulation substances accumulation and its increase "rejecting-salt" capacity of its root. Furthermore, NO can simultaneously increase the absorption of $\mathrm{Ca}^{2+}$ by increasing the cell permeability. Dogan et al. (2010) showed that only the salt-tolerant cultivars maintained higher $\mathrm{Ca}^{2+}$ contents in all tissues of the plant, so promoting absorption of $\mathrm{Ca}^{2+}$ is one way of improving salt tolerance. SNP-induced $\mathrm{K}^{+}, \mathrm{Ca}^{2+}$, and $\mathrm{Mg}^{2+}$ contents in $\mathrm{NaCl}$-treated cotton plants indicates that SNP can play a critical role in modulating cell ion balance, thereby protecting plants against oxidative damage.

An optimum $\mathrm{Na}^{+} / \mathrm{K}^{+}$ratio is an important characteristic of salt tolerant plants. $\mathrm{NaCl}$ stress will greatly affect the selective absorption of $\mathrm{K}^{+}$and $\mathrm{Na}^{+}$, and break the ionic balance (Wang et al., 2011). Some researches showed that NO signaled the increased expression of $\mathrm{PM} \mathrm{H} \mathrm{H}^{+}$-ATPase which increased salt tolerance by increasing the $\mathrm{K}^{+}$to $\mathrm{Na}^{+}$ratio. In the present study, the treatments with SNP showed that NO actually inhibited $\mathrm{Na}^{+}$absorption and maintained a higher $\mathrm{Na}^{+} /$ $\mathrm{K}^{+}$and $\mathrm{Ca}^{2+} \mathrm{Na}^{+}$ratio. This strongly suggests that $\mathrm{NO}$ is involved in "turning off" the antioxidant component of the environmental stress response, perhaps after other acclimation mechanisms such as the accumulation of proline or other low molecular weight compounds that may serve as osmoprotectancts and the adjustment of the $\mathrm{K}^{+}$to $\mathrm{Na}^{+}$ratio are induced (Shantel et al., 2008).

\section{Conclusion}

This study showed that, $\mathrm{NaCl}$ stress restrained the growth and enzyme activity, and disequilibrated ionic homeostasis. While low levels of SNP performed advantageous effects on attenuation of inhibition of seedling growth. Low concentration of NO alleviates $\mathrm{NaCl}$ toxicity and scavenges the ROS by: (1) promoting photosynthetic rate, fluorescence parameters and 
accelerating the growth rate, (2) inducing a better antioxidant system in plants, (3) adjusting cations absorption and membrane permeability. The alleviating effects on the various organs are root $>$ stem $>$ leaf. However, high concentration SNP reduced the cotton salt resistance. All of them were strong evidence to support the physiological role of clearance oxidative stress for proper concentration of exogenous NO in cotton salt-tolerance.

\section{Acknowledgements}

The authors thank English Lecturer Mr Stuart Craig MA (England, Taishan University, Shandong,China) for his critical reading and revision of the manuscript. Special acknowledgements are given to the editors and reviewers. This work was funded by the projects Shandong Provincial Natural Science Foundation, China(No. ZR2013CM003) and the Open Research Fund Program (No.2012KFJ02) of Shandong Provincial Key Laboratory of Eco-Environmental Science for Yellow River Delta (Binzhou University).

\section{Reference}

Arnon, D.I. 1949. Copper enzymes in isolated chloroplasts: polyphenoloxidase in Beta vulgaris. Plant Physiology. 24, (1): 1-15.

Bates, L.S., Waldern, S.P., Teare, I.D. 1973. Rapid determination of free proline for water-stress studies. Plant Soil. 39, 205-207.

Baligar, V.C., Schaffert, R.E., Dos, S.H.L., Pitta, G.V.E., De, C.A.F., Bahia, F. 1993. Growth and nurient uptake parameters in sorghum as influenced by Aluminum. Agronomy Journal. 85, 1068-1074.

Corpas, F.J., Barroso ,J.B., Carreras, A.. Valderrama, R., Palma, J.M., León,A. M., Sandalio, L.M., del Río, L. A. Constitutive arginine-dependent nitric oxide synthase activity in different organs of pea seedlings during plant development. Planta. 224, 246-254.

Cramer, G.R., Alberico, G.J. Schmidt, C. 1994. Salt tolerance is not associated with the sodium accumulation of two maize hybrids. Austr. J. Plant Physiol. 21, 675-692.

Dogan, M., Tipirdamaz, R., Demir, Y. 2010. Salt resistance of tomato species grown in sand culture. Plant, Soil and Environment . 56, (11): 499-507

Rosales, E.P., .Iannone, M.F., Groppa, M.D., Benavides, M.P. 2012. Polyamines modulate nitrate reductase activity in wheat leaves: involvement of nitric oxide. Amino Acids. 42, 57-865

He, Y., Liu, Y., Cao, W., Hua, M., Xu, B., Huang, B. 2005. Effects of salicylic acid on heat tolerance associated with antioxidant metabolism in Kentucky bluegrass. Crop Science. 45, 988-995.

Kaiser, W.M., Huber, S.C. 2001. Post-translational regulation of nitrate reductase: mechanisms, physiological relevance and environmental triggers. Journal of experimental botany. 52, 1981-1989,

Kapila, K.G.D., Xia, Y.P., Zhu, Z.J., Le, C., Wijeratne, A.W. 2010. Some deleterious effects of long-term salt stress on growth, nutrition and physiology of gerbera (Gerbera jamesonii L.) and potential indicators of its salt tolerance. Journal of Plant Nutrition. 33, 2010-2027.

Liang, W.B., Xue, S.G., Shen, J.H., Wang, P. 2010. Effects of manganese stress on photosythesis and chlorophyll fluorescence parameters of Phytolacca americana. Acta Ecologica Sinica. 30, 619-625.

Liu, S., Dong, Y., Xu, L., Kong, J. 2013. Effects of foliar applications of nitric oxide and salicylic acid on salt-induced changes in photosynthesis and antioxidative metabolism of cotton seedlings. Plant Growth Regul. DOI 10.1007/s10725-013-9868-6. 
Li, R.L., Shi, F.C., Yang Y.L. 2010. Effects of salt and alkali stresses on germination, growth, photosynthesis and ion accumulation in alfalfa (Medicago sativa L.). Soil Science and Plant Nutrition. 56, 725-733

Munns, R. 2002. Comparative physiology of salt and water stress. Plant Cell and Environment. 25, 239250 .

Matysik, J., Bhalu, B.A., Mohanty, P. 2002. Molecular mechanism of quenching of reactive oxygen species by proline under stress in plants. Current Science. 82, 525-532

Ons, T.Z., Nehla, L., Ine`s, S., Ahmed, D., Riadh, K., Mokded, R., Abderrazak, S., Chedly, A. 2012. Alleviation of phosphorus deficiency stress by moderate salinity in the halophyte Hordeum maritimum L. Plant Growth Regulation. 66, 7585

Rosales, E.P., , M.F., Groppa, M.D., Benavides, M.P. 2012. Polyamines modulate nitrate reductase activity in wheat leaves: involvement of nitric oxide. Amino Acids. 42, 857-865.

Shi, S., Wang, G., Wang, Y., Zhang L. 2005. Protective effect of nitric oxide against oxidative stress under ultraviolet- $B$ radiation. Nitric Oxide. $13,1-9$.

Singh, H.P., Batish, D.R., Kaur, G., Arora, K., Kohli, R.K. 2008. Nitric oxide (as sodium nitroprusside) supplementation ameliorates $\mathrm{Cd}$ toxicity in hydroponically grown wheat roots. Environmental and Experimental Botany. 63, 158-167.

Shantel A.V., Rocky W.F., Alvarro V., Dalton R.G., Stephen W.B., Juan R. 2008. Opposing roles for superoxide and nitric oxide in the $\mathrm{NaCl}$ stressinduced upregulation of antioxidant enzyme activity in cotton callus tissue. Environmental and Experimental Botany. 62, 60-68.
Tariq, A., Masroor, A.K.M., Teixeira da Silva, J.A., Mohd, I., M. Naeem, Moinuddin. 2011. Role of salicylic acid in promoting salt stress tolerance and enhanced artemisinin production in artemisia annua L. Journal of plant growth regulation. 30, 425-435.

Wang, H.H., Liang, X.L., Wan, Q., Wan, Q., Wang, X.M., Bi, Y.R. 2009. Ethylene and nitric oxide are involved in maintaining ion homeostasis in Arabidopsis callus under salt stress. Planta. 230, 293-307.

Wang, H., Wu, Z., Chen, Y., Yang, C., Shi, D. 2011. Effects of salt and alkali stresses on growth and ion balance in rice (Oryza sativa L.). Plant, Soil and Environment. 57, (6): 286-294.

Xiong, J., Lu, H., Lu, K.X., Duan, Y.X., An, L.Y., Zhu, C. 2009. Cadmium decreases crown root number by decreasing endogenous nitric oxide, which is indispensable for crown root primordia initiation in rice seedlings. Planta. 230, 599-610.

Yaneva, I.A., Hoffmann, G.W., Tischner, R. 2002. Nitrate reductase from winter wheat leaves is activated at low temperature via protein dephosphorylation. Physiol Plant. 114, 65-72.

Yamamoto, A., Sawada, H., Shim, I.S., Usui, K., Fujihara, S. 2011. Effect of salt stress on physiological response and leaf polyamine content in NERICA rice seedlings. Plant, Soil and Environment. 57, (12): 571-576,

Zhang, Y.Y., Liu, Y.L. 2004. Source and function of nitric oxide in plants. Acta Botanica BorealiOccidentalia Sinica. 24, (5):921-929.

Zhang K.W., Guo N., Lian L.J., Wang J., Lv S.L., Zhang J.R. 2011. Improved salt tolerance and seed cotton yield in cotton (Gossypium hirsutum L.) by transformation with betA gene for glycinebetaine synthesis. Euphytica. 181, 1-16. 
Zhang, X.W., Dong, Y.J., Qiu, X.K., Hu, G.Q., Wang, Y.H., Wang, Q.H. 2012. Exogenous nitric oxide alleviates iron-deficiency chlorosis in peanut growing on calcareous soil. Plant, soil and environment. 58, 111-120.
Zheng, C.F., Jiang, D., Liu, F.L., Dai, T.B., Liu, W.C., Jing, Q., Cao, W.X. 2009. Exogenous nitric oxide improves seed germination in wheat against mitochondrial oxidative damage induced by high salinity. Environmental and Experimental Botany. 67, 222-227. 